\title{
PENGARUH MODEL PEMBELAJARAN INKUIRI DAN PENGGUNAAN MEDIA BERBASIS KOMPUTER ( CD MOVIE DAN FLASH) TERHADAP KREATIVITAS SISWA MA KELAS XI PADA POKOK BAHASAN KOLOID
}

\author{
Fuadaturahmah \\ Penulis adalah Dosen Akademi Maritim Belawan Medan
}

\begin{abstract}
Abstrak
The purpose of this study is to reveal the influence of inquiry learning models and the use of computer-based media (movie and flash CDs) on the creativity of class XI MA students on the subject of colloid, this research uses quasi experimental methods by grouping research samples into two group. The two groups are each made into experimental group 1 and experimental group 2. The results of this study are (1) There is an influence of creativity on students' chemistry learning outcomes that are taught by inquiry learning models with computer-based media use (CD Movie and flash) and learning methods conventional with computer-based media (Movie CDs and flash) at the Medan Medan SU IAIN Laboratory. The average creativity of students with inquiry learning models with the use of computer-based media (CD Movie and flash) is 80.77 while the average creativity of students with conventional learning methods with computer-based media (CD Movie and flash) is 79.23. (2) There is a significant interaction ( $\mathrm{p}=0.048$ or $\mathrm{p}<0.05)$ between creativity and inquiry learning models and conventional methods with the use of computer-based media (CD Movie and flash) in influencing student chemistry learning outcomes.
\end{abstract}

\section{Kata kunci: Inkuiri, Media Berbasi Komputer, Kreatifitas Belajar}

\section{PENDAHULUAN}

Pembelajaran merupakan suatu kegiatan yang melibatkan seseorang dalam upaya memperoleh pengetahuan, keterampilan dan nilai-nilai positif dengan memanfaatkan berbagai sumber untuk belajar. Pembelajaran dapat melibatkan dua pihak yaitu siswa sebagai pembelajar dan guru sebagai fasilitator. Kegiatan terpenting dalam pembelajaran adalah proses belajar ( learning proses). Proses belajar memiliki beberapa ciri berikut : (1) Belajar sifatnya disadari, dalam hal ini siswa merasa bahwa dirinya sedang belajar, timbul dalam dirinya motivasi untuk memiliki pengetahuan yang diharapkan. (2) Hasil belajar diperoleh dengan adanya proses, dalam hal ini pengetahuan diperoleh secara tidak spontanitas, instant, melainkan bertahap.

Mengajar kimia tidak mudah dan penuh dengan tantangan. Tantangan tersebut lahir akibat dari berbagai perkembangan iptek yang sangat dinamis. Munculnya pemikiran baru terhadap konsep kimia, meluasnya produk aplikasi kimia di masyarakat, berkembangnya teori-teori pembelajaran, dan tuntutan masyarakat, 
menjadikan perlunya pengkajian ulang tentang pemahaman, sudut pandang, serta tradisi guru dalam mengajar kimia..

Pengalaman pendidikan yang sering dihadapi guru-guru kimia di SMA adalah bahwa kebanyakan siswa menganggap pelajaran kimia sebagai mata pelajaran yang sulit, sehingga siswa terlebih dahulu merasa kurang mampu untuk mempelajarinya (Situmorang, dkk 2003). Hal ini mungkin disebabkan oleh penyajian materi kimia yang kurang menarik dan membosankan, akhirnya terkesan menakutkan bagi siswa, akibatnya banyak siswa yang kurang menguasai konsep dasar kimia. Sebagai akibat dari merasa sulit maka pelajaran kimia menjadi tidak menarik lagi bagi siswa. Dan ini yang menjadi salah satu faktor penyebab rendahnya hasil belajar siswa selama ini.

Masalah yang dihadapi guru kimia di SMA/MA diantaranya adalah kurangnya kreativitas siswa, sekalipun guru telah berusaha semaksimal mungkin untuk mengajar dengan baik. Sesungguhnya masalah ini bukan hanya dalam pengajaran kimia saja melainkan juga pada mata pelajaran IPA lainnya. Fenomena ini menjadi petunjuk tingginya kompleksitas pembelajaran saat ini. Masih perlu pengkajian, penelitian, dan pemikiran yang melibatkan guru-guru dan praktisi pendidikan kimia yang secara bersama-sama mengembangkan alternatif pendekatan dan strategi yang efektif dalam mengajar kimia.

Banyak kritikan terhadap proses dan hasil pembelajaran kimia di sekolah menengah atas termasuk madrasah aliyah. Sejumlah kritik terarah pada kegiatan belajar mengajar yang berpusat pada guru sehingga pembelajaran nampak sebagai ceramah dan sifatnya monoton, yang didalamnya pengetahuan baik fakta, konsep, prinsip dan teori kimia di transmisikan dari guru tanpa menstimulasi peserta didik untuk berpikir atau bernalar. Karakter ilmu kimia sebagai "eksperimental science" tidak tampak dalam kegiatan belajar mengajar kimia, karena sangat jarang siswa distimulasi untuk melakukan observasi terhadap fenomena kimia.

Menurut Sanjaya (2008:196), Strategi Pembelajaran Inkuiri merupakan rangkaian kegiatan pembelajaran yang menekankan pada proses berpikir secara kritis dan analitis untuk mencari dan menemukan sendiri jawaban dari suatu masalah yang dipertanyakan. Proses berpikir itu sendiri dilakukan melalui tanya jawab antara guru dan siswa. Adapun intisari dari pembelajaran inquiri adalah memberi pembelajaran siswa untuk menangani permasalahan yang mereka hadapi ketika berhadapan dengan dunia nyata. Pada pembelajaran inkuiri para guru harus merencanakan situasi 
sedemikian rupa, sehingga siswa bekerja seperti seorang peneliti dengan menggunakan prosedur mengenali permasalahan, menjawab pertanyaan, investigasi, dan menyiapkan kerangka berfikir, hipotesis dan penjelasan yang kompatibel dengan pengalaman pada dunia nyata (Hakim, 2008:59).

Kenyataan yang terjadi di lapangan masih ada guru yang mengajar siswa tanpa mengevaluasi hasil belajarnya. Hal ini mengakibatkan siswa malas dan kurang berminat belajar kimia, sehingga kreativitasnya rendah, dan berpengaruh pada perkembangan kognitifnya. Oleh karena itu perlu upaya kreativitas siswa dengan cara memberdayagunakan fasilitas atau sumber-sumber belajar seperti media yang tepat. Penggunaan komputer dalam pembelajaran sangat menguntungkan karena telah tersedia berbagai jenis software dan hardware yang memudahkan untuk mengintegrasikan komputer dengan peralatan elektronik lain seperti video, camera dan instrumen laboratorium. Pertimbangan utama yang dibutuhkan dalam penggunaan komputer dalam pembelajaran adalah ketersediaan dan kemauan tenaga pengajar untuk menggunakannya dalam inovasi model pembelajaran (Situmorang : 2004). Beberapa media pendidikan yang sering digunakan dalam proses belajar mengajar diantaranya media cetak, elektronik, sketsa, model, peta dan diagram (Kreyenhbuhl, 1991).

Berdasarkan ulasan diatas maka diajukan penelitian dengan judul" Pengaruh Model Pembelajaran Inkuiri dan Penggunaan Media berbasis komputer ( $C D$ Movie dan Flash) Terhadap Kreativitas Siswa MA Kelas XI Pada Pokok Bahasan Koloid".

\section{KAJIAN TEORI}

\section{Hakikat Model Pembelajaran Inkuiri}

Menurut Joyce dan Weil (2000:13), model pembelajaran diartikan suatu rencana pembelajaran yang memperlihatkan urutan kegiatan atau fase pembelajaran dimana fase ini tergambarkan kegiatan dan peran guru-siswa di dalam mewujudkan kondisi belajar atau sistem lingkungan kelas yang menyebabkan terjadinya belajar, dengan kata lain model pembelajaran akan memperlihatkan urutan penyajian pengajaran dengan tahapan-tahapan pengajaran sesuai dengan teori belajar yang digunakan sebagai acuannya.

Inkuiri pada dasarnya adalah cara menyadari apa yang telah di alami. Karena itu inquiri menuntut peserta didik berpikir. Metode ini menempatkan peserta didik 
pada situasi yang melibatkan mereka dalam kegiatan intelektual.metode ini menuntut peserta didik memproses pengalaman belajar menjadi sesuatu yang bermakna dalam kehidupan nyata. Dengan demikian, melalui metode ini peserta didik dibiasakan untuk produktif, analitis dan kritis.(Mulyasa, 2002:235)

Ada beberapa hal yang menjadi ciri utama strategi pembelajaran inkuiri. Pertama, strategi inquiri menekankan kepada aktivitas siswa secara maksimal untuk mencari dan menemukan, artinya strategi inkuiri menempatkan siswa sebagai subjek belajar. Dalam proses pembelajaran, siswa tidak hanya brperan sebagai penerima pelajaran melalui penjelasan verbal, tetapi mereka berperan untuk menemukan sendiri inti dari materi pelajaran itu sendiri.

Kedua, seluruh aktivitas yang dilakukan siswa di arahkan untuk mencari dan menemukan jawaban sendiri dari sesuatu yang dipertanyakan, sehingga diharapkan dapat menumbuhkan sikap percaya diri. Dengan demikian, strategi pembelajaran inkuiri menempatkan guru bukan sebagai sumber belajar, akan tetapi sebagai fasilitator dan motivator belajar siswa.

Ketiga, tujuan dari penggunaan strategi pembelajaran inkuiri adalah mengembangkan kemampuan berpikir secara sistematis, logis, dan kritis, atau mengembangkan kemampuan intelektual sebagai bagian dari proses mental. Dengan demikian, dalam strategi pembelajaran inkuiri siswa tak hanya dituntut agar menguasai materi pelajaran, akan tetapi bagaimana mereka dapat menggunakan potensi yang dimilikinya.

Model pembelajaran inkuiri yang digunakan dalam penelitian ini menggunakan model inkuiri training yang memiliki lima tahapan yang diajukan oleh Richard Suchman (Howar Jones). Dalam pembelajaran ini, guru memberikan permasalahan yang akan dipecahkan oleh siswa sesuai dengan kompetensi dasar dan tingkat perkembangan anak, selanjutnya usaha siswa untuk menemukan cara pemecahan masalah melalui pengumpulan informasi, melakukan eksperimen, mencatat informasi tersebut, merumuskan penjelasan untuk mengorganisir data serta merumuskan penjelasan terhadap masalah, dan akhirnya siswa mengadakan analisis hasil temuannya. Model pembelajaran inkuiri ini akan berjalan dengan baik jika dalam prakteknya dapat dijalankan dengan setting arahan guru. Setting ini menuntut siswa agar memiliki akses untuk bahan yang dibutuhkan dan mampu berperan aktif dalam kelompoknya. 


\section{Keunggulan Dan Kelemahan Pembelajaran Inkuiri}

Pembelajaran inquiri merupakan strategi pembelajaran yang banyak di anjurkan oleh karena strategi ini memiliki beberapa keunggulan, di antaranya :

a. Pembelajaran Inkuiri merupakan strategi pembelajaran yang menekankan pada pengembangan aspek kognitif, afektif, dan psikomotor secara seimbang, sehingga pembelajaran melalui strategi ini di anggap lebih bermakna.

b. Pembelajaran Inkuiri dapat memberikan ruang kepada siswa untuk belajar sesuai dengan gaya belajar mereka.

c. Pembelajaran Inkuiri merupakan strategi yang di anggap sesuai dengan perkembangan. Psikologi belajar modern yang menganggap belajar adalah proses perubahan tingkah laku berkat adanya pengalaman.

d. Keuntungan lain adalah strategi pembelajaran ini dapat melayani kebutuhan siswa yang memiliki kemampuan di atas rata-rata, artinya, siswa yang memiliki kemampuan belajar bagus tidak akan terhambat oleh siswa yang lemah dalam belajar (Sanjaya, 2008:208).

Disamping memiliki keunggulan, pembelajaran inkuiri juga mempunyai kelemahan, di antaranya:

a. Jika pembelajaran inkuiri digunakan sebagai strategi pembelajaran, maka akan sulit mengontrol kegiatan dan keberhasilan siswa.

b. Strategi ini sulit dalam merencanakan pembelajaran oleh karena terbentur dengan kebiasaan siswa dalam belajar.

c. Kadang-kadang dalam mengimplementasikannya, memerlukan waktu yang panjang sehingga guru sulit menyesuaikannya dengan waktu yang telah ditentukan.

d. Selama kriteria keberhasilan belajar ditentukan oleh kemampuan siswa menguasai materi pelajaran, maka pembelajaran inkuiri akan sulit di implementasikan oleh setiap guru (Sanjaya, 2008:208).

\section{Media Pembelajaran Berbasis Komputer.}

Media komputer merupakan media yang menarik bahkan atraktif dan interaktif. Pembelajaran dengan menggunakan media komputer sesungguhnya membekalkan pada setiap orang dengan berbagai karakter yang menjadi kekuatan dan kelemahan suatu media, bagaimana suatu media itu bekerja mengemas informasi (Munir, 2008:144). 
Komputer adalah suatu alat elektronik yang mampu melakukan beberapa tugas seperti: (a) memproses data input sesuai dengan programnya; (b) menyimpan perintah-perintah dan hasil-hasil dari pengolahan data; (c) menyediakan output data dalam bentuk informasi. Sedangkan menurut Hamacher, komputer adalah alat hitung mesin elektronik yang cepat dan dapat menerima input digital kemudian memprosesnya sesuai dengan program yang tersimpan dimemorinya, dan menghasilkan data output berupa informasi.

Beberapa hal yang perlu di siapkan dalam pembelajaran menggunakan media komputer, antara lain dari sisi peserta didik : (1) pelajari software terlebih dahulu, (2) kalau memungkinkan satu peserta satu komputer.(3) gunakan infocus untuk penjelasan.(4) amati kerja peserta satu persatu.(5) jelaskan prosedur pengoperasian dengan bahasa yang jelas. Sedangkan dari sisi pengajar : (1) pengajar sebaiknya sudah dapat mengoperasikan LCD dan komputer. (2) cantumkan poin-poin penting aja dalam power point.(3) gunakan warna-warna yang menarik.(4) gunakan animasi secukupnya agar tidak mengganggu.(5) kalau bisa sebaiknya hindari suara yang ditimbulkan dari animasi.(6) gunakan animasi gambar.(7) gunakan foto secukupnya (8) gunakan film pendek.(9) prinsip satu slide satu menit.(10) jangan terlalu banyak slide, maksimal 20 slide tiap sesi.(Munir, 2008:145)

Secara umum pengertian komputer adalah serangkaian mesin elektronik yang terdiri dari komponen-komponen yang dapat saling bekerja sama yang rapi dan teliti.system ini kemudian dapat digunakan untuk melaksanakan berbagi jenis pekerjaan secara otomatis berdasarkan urutan intruksi maupun program yng diberikan kepadanya. Akhirnya media komputer tersebut banyak digunakan dalam aktivitas proses belajar mengajar di sekolah.

Penggunaan media komputer dalam pembelajaran sains dapat meningkatkan efesiensi dan efektivitas pembelajaran, sehingga membutuhkan inovator yang terampil dan berpengalaman (Situmorang, 2003). Pembelajaran efektif adalah yang menghasilkan belajar yang bermanfaat dan bertujuan bagi para siswa, melalui strategi pembelajaran yang tepat. Keefektifan pembelajaran biasanya diukur dengan tingkat pencapaian siswa. Ada empat aspek penting yang dapat dipakai untuk mempreskripsikan keefektifan pembelajaran, yaitu (1) kecermatan penguasaan perilaku yang dipelajari yang sering disebut dengan tingkat kesalahan. (2) kecepatan unjuk kerja. (3) tingkat alih belajar.(4) tingkat retensi dari apa yang dipelajari (Uno, 
2006:21). Adapun faktor-faktor yang mempengaruhi efektivitas belajar adalah: (a) siswa; (b) guru; (c) tujuan belajar; (d) materi pelajaran; (e) sarana belajar; (f) interaksi siswa dengan mata pelajaran; (g) interaksi guru dengan siswa; (h) interaksi antar siswa; (i) Lingkungan belajar

Media komputer merupakan media yang menarik bahkan interaktif. Pembelajaran dengan menggunakan media komputer sesungguhnya membekalkan pada setiap orang dengan berbagai karakter yang menjadi kekuatan dan kelemahan dari suatu media. Pendidikan melalui media elektronik sesungguhnya sudah di mulai dari lingkungan keluarga Munir, 2008:144). Teknologi komputer sebagai media informasi merupakan media yang efektif bagi seorang guru dalam merancang media pembelajaran sehingga dapat mempermudah tugas guru. Dengan media komputer guru akan lebih mudah menyampaikan materi yang abstrak sehingga siswa dapat memahami konsep-konsep yang sulit diperagakan secara manual. Dengan media komputer guru akan lebih efektif dan efisien dalam menyajikan materi pembelajaran.

Model pembelajaran berbasis komputer marupakan model pembelajaran yang dikombinasikan antara model pembelajaran dengan penggunaan media komputer. Dimana aplikasi komputer sebagai alat bantu proses pembelajaran memberikan beberapa keuntungan, antara lain: (a) komputer dapat mengakomodasikan individu yang lamban menerima suatu bentuk pemahaman, sebaliknya komputer dapat memberikan iklimyang lebih bersifat efektif untuk individual, tidak pernah lupa, tidak pernah bosan, sangat sabar dalam menjalankan instruksi seperti yang yang diinginkan program yang digunakan; (b) komputer dapat merangsang individu untuk mengerjakan latihan melakukan kegiatan laboratorium atau simulasi karena tersedianya animasi grafik, warna dan musik, yang dapat menambah realisme; (c) kendala ada pada individu yang bersangkutan, sehingga tingkat kecepatan pemahamannya dapat disesuaikan dengan tingkat penguasaannya karena komputer dapat berinteraksi dengan seseorang secara perorangan; (d) kemampuan untuk merekam aktivitas selama menggunakan suatu program pekerjaan tertentu memberikan kesempatan yang lebih baik untuk pemahaman perorangan dan perkembangan selalu dapat dipantau.

\section{Hakekat Kreativitas Dalam Pembelajaran}

Perkembangan kreativitas sangat erat kaitannya dengan perkembangan kognitif. Karena kreativitas merupakan perwujudan dari pekerjaan otak. Para pakar 
kreativitas, misalnya Clark melalui "Teori belahan otak" mengungkapkan bahwa sesungguhnya otak manusia itu menurut fungsinya terbagi dua belahan, yakni belahan otak kiri dan belahan otak kanan. Fungsi otak belahan kiri adalah berkaitan dengan pekerjaan yang bersifat ilmiah, kritis, logis, linier, teratur, sistematis, terorganisir, beraturan, dan sejenisnya. Adapun fungsi otak belahan kanan adalah berkenaan dengan kegiatan yang bersifat non linier, non verbal, holistik, humanistik, kreatif, mencipta, mendesain, dan sejenisnya. Singkatnya, otak belahan kiri mengarah kepada cara-cara berfikir konvergen, sedangkan otak belahan kanan mengarah kepada cara-cara berfikir menyebar.

Barron mendefenisikan kreativitas adalah kemampuan untuk menciptakan sesuatu yang baru. Guilford manyatakan bahwa kreativitas mengacu pada kemampuan yang menandai ciri-ciri seorang kreatif. Munandar mendefenisikan kreativitas sebagai kemampuan yang mencerminkan kelancaran, keluwesan, dan orisinalitas dalam berfikir serta kemampuan untuk mengelaborasi suatu gagasan.

Adapun faktor-faktor yang menentukan kreativitas seperti inteligensi, bakat, motivasi, sikap, minat dan disposisi kepribadian lainnya. Dan faktor-faktor yang mempengaruhi kreativitas adalah : Usia, tingkat pendidikan orang tua, tersedianya fasilitas, penggunaan waktu luang. Clark menganggap bahwa kreativitas mencakup sintesis dari fungsi sebagai berikut : (1) Thinking, (2) Feeling, (3) Sensing, (4) Intuiting. Arieti (1976) mengemukakan beberapa faktor sosiologis yang kondusif bagi perkembangan kreativitas, yaitu : (1) Tersedianya sarana prasarana, (2) Keterbukaan terhadap keragaman cara berfikir (3) Adanya keleluasaan (4) Adanya toleransi terhadap pandangan yang divergen (5) Adanya penghargaan terhadap orang yang berprestasi.

Ada empat tahap proses kreatif siswa : (1) Persiapan (2) Inkubasi (3) Iluminasi (4) Ferifikasi. Ada juga karakteristik kreativitas siswa yang dikemukakan oleh Piers Adams yaitu : (1) Memiliki dorangan yang tinggi (2) Memiliki rasa ingin tahu yang besar (3) Mimiliki ketekunan yang tinggi (4) Cenderung tidak puas pada kemampuan (5) Penuh percaya diri (6)Memiliki kemandirian yang tinggi (7) Bebas dalam mengambil keputusan (8) Menerima diri sendiri (9) Memiliki intuisi yang tinggi (10) Cenderung tertarik pada hal-hal yang kompleks (11) Toleran terhadap ambiguitas (12) Bersifat sensitif (Asrori, 2007:60) 


\section{METODE PENELITIAN}

Penelitian ini akan dilaksanakan di Madrasah Aliyah Laboratorium IAIN SU Medan. Waktu penelitian direncanakan pada bulam Mei - Juni tahun pelajaran 2009/2010 di semester II kelas XI. Penelitian ini akan dilakukan dengan RPP 3 kali pertemuan di lakukan pada bulai mei dan penelitian akan diakhiri pada bulan juni.

Populasi adalah keseluruhan subjek penelitian apabila seseorang ingin meneliti semua elemen yang ada dalam wilayah penelitian, maka penelitiannya merupakan penelitian populasi.(Arikunto, 2006:130). Jadi, berdasarkan tujuan penelitian ini maka populasi dalam penelitian adalah semua siswa kelas XI IPA, di Madrasah Aliyah Laboratorium IAIN SU Medan yang terdiri dari 2 kelas, dengan jumlah seluruh siswa sebanyak 60 siswa.

Seluruh populasi menjadi sampel dalam penelitian ini. Teknik penarikan sampel dilakukan dengan cara Total Sampling. Pengambilan sampel didasarkan atas adanya tujuan tertentu. Teknik ini dilakukan karena beberapa pertimbangan, sehingga tidak dapat mengambil smapel yang besar dan jauh (Arikunto, 2006:139)

Jenis penelitian yang digunakan adalah eksperimental semu (quasi eksperimental) yaitu dengan mengelompokkan sampel penelitian menjadi dua kelompok. Kedua kelompok tersebut masing-masing dijadikan kelompok eksperimen 1 dan kelompok eksperimen 2. Pada kelompok eksperimen 1 dilakukan proses pembelajaran dengan metode pendekatan inkuiri dan menggunakan media komputer dengan metode konvensional dan menggunakan media berbasis komputer.. Pada akhir penelitian, hasil belajar siswa dari kelompok eksperimen 1 dan kelompok eksperimen 2 dibandingkan dan diuji dengan analisis statistik untuk melihat seberapa jauh perbedaan hasil belajar.

\section{HASIL PENELITIAN DAN PEMBAHASAN}

Hasil belajar kimia dengan menggunakan Strategi Pembelajaran Inkuiri dengan Media Berbasis Komputer (CD Movie dan Flash) dan Pembelajaran Konvensional dengan Media Komputer (CD Movie dan Flash).

\section{Pengujian Hipotesis Penelitian}

Untuk menguji ketiga hipotesis penelitian dilakukan uji-T Berpasangan. Pertama untuk melihat pengaruh model pembelajaran inkuiri dan metode pembelajaran konvensional dengan penggunaan media berbasis komputer (CD Movie dan flash) 
terhadap hasil belajar kimia siswa di MA Laboratorium IAIN SU Medan, kedua adalah untuk melihat pengaruh kreativitas terhadap hasil belajar kimia siswa yang dibelajarkan dengan model pembelajaran inkuiri dan metode pembelajaran konvensional dengan penggunaan media berbasis komputer (CD Movie dan flash) di MA.Laboratorium IAIN SU Medan dan ketiga untuk melihat kreativitas belajar kimia siswa pada kedua perlakuan menggunakan uji Regresi.

Interaksi antara kreativitas dan model pembelajaran inkuiri dengan penggunaan media berbasis komputer (CD Movie dan flash) dan metode pembelajaran konvensional dengan media berbasis komputer ( $C D$ Movie dan flash) dalam mempengaruhi hasil belajar kimia siswa di MA.Laboratorium IAIN SU Medan.

Pada hasil perhitungan SPSS 15. dapat diperoleh uji statistik Uji Regresi terhadap Interaksi antara kreativitas dan model pembelajaran inkuiri dan metode konvensional dengan penggunaan media berbasis komputer (CD Movie dan flash) dalam mempengaruhi hasil belajar kimia siswa di MA.Laboratorium IAIN SU Medan.

Tabel 4.8. Statistik Interaksi antara kreativitas dan model pembelajaran inkuiri dengan penggunaan media berbasis komputer ( $C D$ Movie dan flash) dan metode pembelajaran konvensional dengan media berbasis komputer (CD Movie dan flash) dalam mempengaruhi hasil belajar kimia siswa di MA.Laboratorium IAIN SU Medan.

\section{Descriptive Statistics}

\begin{tabular}{|l|r|r|r|}
\hline & \multicolumn{1}{|c|}{ Mean } & Std. Deviation & \multicolumn{2}{c|}{ N } \\
\hline Nilai &, 5807 &, 14428 & 60 \\
Kreativitas & 80,00 & 11,949 & 60 \\
\hline
\end{tabular}

Rata-rata nilai siswa adalah sebesar 0,5807 (dengan standar deviasi 0,14428). Dan rata-rata kreativitas siswa adalah sebesar 80,00 (dengan standar deviasi $11,949)$.

\section{Correlations}

\begin{tabular}{|ll|r|r|}
\hline & & \multicolumn{2}{|c|}{ nilai } \\
\hline \multirow{4}{*}{ Sig. (1-tailed) } & Nilai & 1,000 & \multicolumn{2}{|c|}{ Kreativitas } \\
& kreativitas &, 189 &, 189 \\
$\mathrm{~N}$ & Nilai & $\cdot$ & 1,000 \\
& Kreativitas &, 074 &, 038 \\
& Nilai & 60 & 6 \\
& kreativitas & 60 & 60 \\
\hline
\end{tabular}


Interaksi antara kreativitas dan model pembelajaran inkuiri dan metode konvensional dengan penggunaan media berbasis komputer (CD Movie dan flash) dalam mempengaruhi hasil belajar kimia siswa, memiliki interaksi yang signifikan karena memiliki nilai $\mathrm{p}=0,038$ atau $\mathrm{p}<0,05$, dan nilai $\mathrm{r}=0,189$ menunjukkan adanya hubungan atau interaksi dengan korelasi yang kuat.

\section{Model Summary(b)}

\begin{tabular}{|l|r|r|r|r|}
\hline Model & $\mathrm{R}$ & R Square & Adjusted R Square & Std. Error of the Estimate \\
\hline 1 &, 189 (a) &, 036 &, 019 &, 14289 \\
\hline
\end{tabular}

a Predictors: (Constant), kreativitas

b Dependent Variable: nilai

nilai $\mathrm{R}=0,189$ dan $\mathrm{R}$ square $=0,036$, ini menunjukkan bahwa 0,036 atau $3,6 \%$ nilai siswa dipengaruhi oleh kreativitas siswa. Standar error of estimate $=0,14289$ lebih kecil dari standart deviasi $=0,14428$, maka model regresi layak digunakan. Kelayakkan model regresi dapat ditunjukkan melalui Uji Anova.

$\operatorname{ANOVA}(\mathbf{b})$

\begin{tabular}{|ll|l|l|l|l|l|}
\hline \multirow{2}{*}{ Model } & & $\begin{array}{l}\text { Sum of } \\
\text { Squares }\end{array}$ & $\mathrm{df}$ & Mean Square & F & Sig. \\
\hline 1 & Regression &, 044 & 1 &, 044 & 2,155 &, $048(\mathrm{a})$ \\
& Residual & 1,184 & 58 &, 020 & & \\
& Total & 1,228 & 59 & & & \\
\hline
\end{tabular}

a Predictors: (Constant), kreativitas

b Dependent Variable: nilai

\section{Coefficients(a)}

\begin{tabular}{|ll|l|l|l|l|l|}
\hline \multirow{2}{*}{ Model } & \multicolumn{2}{|l|}{$\begin{array}{l}\text { Unstandardized } \\
\text { Coefficients }\end{array}$} & $\begin{array}{l}\text { Standardized } \\
\text { Coefficients }\end{array}$ & $\mathrm{t}$ & Sig. \\
\hline \multirow{2}{*}{1} & B & Std. Error & Beta & B & Std. Error \\
\hline & (Constant) &, 398 &, 126 & & 3,160 &, 003 \\
& kreativitas &, 002 &, 002 &, 189 & 1,468 &, 048 \\
\hline
\end{tabular}

a Dependent Variable: nilai

uji anova menghasilkan angka F sebesar 2,155 dengan p sebesar 0,048. Oleh karena $\mathrm{p}<0,005$, maka regresi dapat dipakai untuk memprediksikan interaksi kreativitas dengan medel pembelajaran dalam mempengaruhi hasil belajar siswa. Nilai B constant 0,398 menyatakan bahwa jika kreativitas di abaikan, maka nilai siswa sebesar 0,398. Jika nilai B kreativitas 0,002 menyatakan bahwa setiap peningkatan kreativitas, nilai akan meningkat sebesar 0,002. Probabilitas $=0,048$ atau $\mathrm{p}<0,005$, 
berarti koefisien regresi signifikan, atau ada Interaksi antara kreativitas dan model pembelajaran inkuiri dan metode konvensional dengan penggunaan media berbasis komputer (CD Movie dan flash) dalam mempengaruhi hasil belajar kimia siswa.

\section{PEMBAHASAN HASIL PENELITIAN}

Berdasarkan hasil-hasil yang diperoleh dalam pengujian hipotesis dapat dikemukakan bahwa:

Interaksi antara kreativitas dan model pembelajaran inkuiri dengan penggunaan media berbasis komputer (CD Movie dan flash) dan metode pembelajaran konvensional dengan media berbasis komputer ( $C D$ Movie dan flash) dalam mempengaruhi hasil belajar kimia siswa di MA.Laboratorium IAIN SU Medan.

Interaksi antara kreativitas dan model pembelajaran inkuiri dan metode konvensional dengan penggunaan media berbasis komputer (CD Movie dan flash) dalam mempengaruhi hasil belajar kimia siswa, memiliki interaksi yang signifikan karena memiliki nilai $\mathrm{p}=0,038$ atau $\mathrm{p}<0,05$, dan nilai $\mathrm{r}=0,189$ menunjukkan adanya hubungan atau interaksi. Dan di lanjutkan dengan uji anova menghasilkan angka $\mathrm{F}$ sebesar 2,155 dengan $\mathrm{p}$ sebesar 0,048. Oleh karena $\mathrm{p}<0,005$, maka regresi dapat dipakai untuk memprediksikan interaksi kreativitas dengan medel pembelajaran dalam mempengaruhi hasil belajar siswa. Nilai Probabilitas $=0,048$ atau $\mathrm{p}<0,005$, berarti koefisien regresi signifikan, atau ada Interaksi antara kreativitas dan model pembelajaran inkuiri dan metode konvensional dengan penggunaan media berbasis komputer (CD Movie dan flash) dalam mempengaruhi hasil belajar kimia siswa.

Pada kelompok yang memiliki kreativitas belajar tinggi, terlihat adanya ketekunan dan kesungguhan dalam belajar, kerja keras dalam belajar, saling bersaing dalam memperlihatkan usaha dan senang dalam belajar dan merasa tidak puas bila belum memahami konsep dan materi yang dipelajari. Adanya penggunaan strategi pembelajaran inkuiri dengan penggunaan media berbasis komputer ( $C D$ Movie dan flash) dapat memperkuat pemahaman materi yang disajikan dan menjadi lebih bermakna dalam struktur kognitif siswa, karena Inkuiri pada dasarnya adalah cara menyadari apa yang telah di alami. Karena itu inkuiri menuntut peserta didik berpikir dan kreatif. Metode ini menempatkan peserta didik pada situasi yang melibatkan mereka dalam kegiatan intelektual.metode ini menuntut peserta didik memproses 
pengalaman belajar menjadi sesuatu yang bermakna dalam kehidupan nyata. Dengan demikian, melalui metode ini peserta didik dibiasakan untuk produktif, analitis dan kritis.(Mulyasa, 2002:235).

\section{SIMPULAN}

Berdasarkan temuan-temuan yang diperoleh dan dipaparkan dalam hasil dan pembahasan penelitian, maka dapat diambil kesimpulan sebagai berikut:

Terdapat pengaruh kreativitas terhadap hasil belajar kimia siswa yang dibelajarkan dengan model pembelajaran inkuiri dengan penggunaan media berbasis komputer (CD Movie dan flash) dan metode pembelajaran konvensional dengan media berbasis komputer (CD Movie dan flash) di MA Laboratorium IAIN SU Medan. Rata-rata kreativitas siswa dengan model pembelajaran inkuiri dengan penggunaan media berbasis komputer (CD Movie dan flash) sebesar 80,77 sedangkan rata-rata kreativitas siswa dengan metode pembelajaran konvensional dengan media berbasis komputer (CD Movie dan flash) sebesar 79,23.

Ada interaksi yang signifikan ( $\mathrm{p}=0,048$ atau $\mathrm{p}<0,05)$ antara kreativitas dan model pembelajaran inkuiri dan metode konvensional dengan penggunaan media berbasis komputer (CD Movie dan flash) dalam mempengaruhi hasil belajar kimia siswa

\section{DAFTAR PUSTAKA}

Arikunto, S., (2006). Prosedur Penelitian Suatu Pendekatan Praktek. Jakarta : Rineka Cipta.

Asrori., M., (2007)., Psikologi Pembelajaran. Bandung : Wacana Prima.

Hakim., L., (2008). Perencanaan Pembelajaran. Bandung : Wacana Prima.

Joyce, B., dan Weil, M.,(2000,) Model Of Teaching, Foreword by James. Wolfsixth Edition, Amerika.

Munir., (2008). Kurikulum Berbasis Teknologi Informasi dan Komunikasi. Bandung : Alfabeta.

Mulyasa., (2004). Kurikulum Berbasis Kompetensi. Bandung : Remaja Rosdakarya. Sanjaya, W., (2006). Strategi Pembelajaran Berorientasi Standar Proses Pendidikan. Jakarta : Kencana. 
Situmorang, M., (2004), Inovasi Model Pembelajaran Bidang Sain untuk Meningkatkan Prestasi Belajar Mahasiswa,Prosiding Konaspi V Surabaya Tahun 2004.

Situmorang, M dkk, (2003), Inovasi Pembelajaran Pada Mata Kuliah Kimia Analiti I, Laporan Hasil Penelitian, FMIPA Universitas Negeri Medan.

Situmorang, M., (2003), Efektivitas Model Pembelajaran Terhadap Peningkatan Prestasi Belajar Mahasiswa Dalam Perkuliahan Kimia Analitik-1, Laporan Hasil Penelitian, FMIPA Universitas Negeri Medan.

Uno., B., H., (2006). Perencanaan Pembelajaran. Jakarta : Bumi Aksara. 